\title{
A Highly Efficient and Stable Visible-Light Plasmonic Photocatalyst Ag-AgCl/CeO
}

\author{
Hongjuan Wang, Lin Yang, Hao Yu, Feng Peng* \\ The School of Chemistry and Chemical Engineering, South China University of Technology, Guangzhou, China \\ E-mail: ${ }^{*}$ cefpeng@scut.edu.cn \\ Received September 15, 2011; revised September 27, 2011; accepted October 29, 2011
}

\begin{abstract}
Noble metal Ag nanoparticles with unique surface plasmon resonance property have attracted much attention recently in the field of photocatalysis. Based on the advantages of $\mathrm{Ag}$ nanoparticles and semiconductor $\mathrm{CeO}_{2}$, a novel plasmonic photocatalyst $\mathrm{Ag}-\mathrm{AgCl} / \mathrm{CeO}_{2}$ was prepared with a facile route. The as-prepared samples were characterized using scanning and transmission electron microscopy, X-ray photoelectron spectroscopy and UV-vis diffusion reflection spectroscopy. This metal-semiconductor nanocomposite plasmonic photocatalyst exhibited a high visible-light photocatalytic activity and good stability for photocatalytic degradation of methyl orange in water. $\mathrm{Ag}-\mathrm{AgCl} / \mathrm{CeO}_{2}$ will be a potentially promising plasmonic photocatalysts for organic pollutant degradation and water purification.
\end{abstract}

Keywords: Plasmonic Photocatalyst, Ag Nanoparticle, AgCl, Visible Light, Photocatalytic Degradation

\section{Introduction}

Due to its high efficiency, low cost and availability, $\mathrm{TiO}_{2}$ has appeared as a leading photocatalyst candidate since 1970s [1]. However, $\mathrm{TiO}_{2}$ can only absorb UV light due to its high band gap energy and then cause its low efficient utilization of solar energy [2-7]. During the last decade, a considerable number of new photocatalytic materials have been proposed as potential substitutes of $\mathrm{TiO}_{2}$ [8]. $\mathrm{CeO}_{2}$, as an n-type semiconductor, is one of them. With a band-gap of $2.9-3.2 \mathrm{eV}$, it has some properties like titania, such as nontoxicity and high stability $[9,10]$. So far, $\mathrm{CeO}_{2}$ are mainly applied in solid oxide fuel cells, oxygen gas sensors, fluorescent materials, metal oxide semiconductor devices, and three way catalysts in vehicle emission control systems and ultraviolet blocking materials, etc. [11-13]. As a potential photocatalyst for the oxidation of pollutants, $\mathrm{CeO}_{2}$ is less active than $\mathrm{TiO}_{2}$ under UV irradiation [14-16]. But it can be activated by visible light [8].

Noble-metal nanoparticles (NPs) can give strong visiblelight absorption because of their size- and shape-dependent plasmon resonance [17]. In particular, Ag NPs show efficient surface plasmon resonance (SPR), which can dramatically enhance the photocatalysts' absorption in the visible region $[18,19]$. This character has been utilized to develop a plasmonic photocatalyst, which has become a hotspot in the field of photocatalyst in recent years. In some researchers' work, noble metal nanoparti= cles were doped in semi-conductors or combined with other non-photoelectric response materials to increase their photocatalytic performance under visible light. In Awazu's report [18], $\mathrm{Ag} / \mathrm{SiO}_{2} / \mathrm{TiO}_{2}$ plasmonic photocatalyst was constructed with Ag NPs as core and the silica as shell to prevent oxidation of $\mathrm{Ag}$ by direct contact with $\mathrm{TiO}_{2}$. The results showed that the degradation rate of methylene blue (MB) was greatly boosted by the assistance of the SPR effect of the contacted silver nanoparticles under near-UV irradiation. Sun et al. [20] demonstrated that Ag@C core/shell nanocomposite synthesized by a hydrothermal process was photoactive in destroying aqueous tetraethylated rhodamine $(\mathrm{RhB})$ and gaseous acetaldehyde $\left(\mathrm{CH}_{3} \mathrm{CHO}\right)$ under visible-light irradiation. Besides using Ag NPs, silver halides were also used in the plasmonic photocatalyst [21]. Wang et al. [22-25] utilized the silver halides to develop Ag@AgX plasmonic photocatalysts with high activity and stability under visible light. The improved photocatalytic activity of the silver halides was attributed to the plasmon resonance of Ag NPs from Ag halides reduced on the surface under irradiation [26]. Hu et al. [27-29] prepared $\mathrm{Ag}-\mathrm{AgBr} / \mathrm{TiO}_{2}$, $\mathrm{Ag} / \mathrm{AgBr} / \mathrm{Al}_{2} \mathrm{O}_{3}$ and $\mathrm{Ag} / \mathrm{AgI} / \mathrm{Al}_{2} \mathrm{O}_{3}$ plasmonic photocatalyst by deposition-precipitation and photor-eduction method to destruct azodyes and bacteria under visible light. On 
the basis of electron spin resonance and cyclic voltammetry analysis, plasmon-induced photocatalytic mechanism was proposed, in which there were two electron transfer processes. $\mathrm{O}_{2}^{-}$and excited $\mathrm{h}^{+}$on Ag NPs, as the main active species, were involved in the photoreaction system of $\mathrm{Ag} / \mathrm{AgI} / \mathrm{Al}_{2} \mathrm{O}_{3}$ and $\mathrm{Ag} / \mathrm{AgBr} / \mathrm{Al}_{2} \mathrm{O}_{3}$.

In this work, based on the advantages of $\mathrm{Ag}$, silver halides and semiconductor $\mathrm{CeO}_{2}$, a novel plasmonic photocatalyst $\mathrm{Ag}-\mathrm{AgCl} / \mathrm{CeO}_{2}$ was designed and prepared. The results showed that the synthesized catalysts had higher photoactivity and stability, showing the potential of Ag$\mathrm{AgCl} / \mathrm{CeO}_{2}$ as a promising photocatalytic material for organic pollutant degradation under visible light.

\section{Experimental Section}

\subsection{Preparation of the Catalysts}

All the chemicals used were analytical grade and used without further purification. $\mathrm{CeO}_{2}$ was purchased from Rare Chemical Corporation of China. To prepare the $\mathrm{AgCl} / \mathrm{CeO}_{2}$, the deposition-precipitation method was adopted. In a typical experiment, $1 \mathrm{~g} \mathrm{CeO}_{2}$ was added into $100 \mathrm{~mL}$ deionized water and sonicated for $30 \mathrm{~min}$ to form a suspension, followed by the addition of $0.1 \mathrm{~g}$ $\mathrm{AgNO}_{3}$ and kept stirring for $30 \mathrm{~min}$. Then $1 \mathrm{M} \mathrm{HCl}$ solution was added, and kept stirring for another $60 \mathrm{~min}$. After that, the resulting suspension was centrifuged and washed with deionized water until $\mathrm{pH}=7$. The obtained solid paste was dried at around $90^{\circ} \mathrm{C}$ overnight to obtain $\mathrm{AgCl} / \mathrm{CeO}_{2}$.

$\mathrm{Ag}-\mathrm{AgCl} / \mathrm{CeO}_{2}$ was prepared via a photo-reduction method. A suspension of $\mathrm{AgCl} / \mathrm{CeO}_{2}$ in deionized water was formed by sonication for $15 \mathrm{~min}$, and then irradiated with a $300 \mathrm{~W} \mathrm{Hg}$ lamp for $20 \mathrm{~min}$ to reduce some $\mathrm{Ag}^{+}$to $\mathrm{Ag}$. The resulting product with some silver NPs deposited on $\mathrm{AgCl} / \mathrm{CeO}_{2}$ was washed and dried in the air to obtain $\mathrm{Ag}-\mathrm{AgCl} / \mathrm{CeO}_{2}$.

For comparison, $\mathrm{Ag} / \mathrm{CeO}_{2}$ with the same $\mathrm{Ag}$ content as that of $\mathrm{Ag}-\mathrm{AgCl} / \mathrm{CeO}_{2}$ was also prepared with incipient wetness impregnation method at room temperature. The samples were dried at $120^{\circ} \mathrm{C}$ for $2 \mathrm{~h}$, calcined in air at $600^{\circ} \mathrm{C}$ for $6 \mathrm{~h}$ and then reduced in a flow of $\mathrm{H}_{2} / \mathrm{N}_{2}(20$ vol $\% \mathrm{H}_{2}, 50 \mathrm{~mL} \cdot \mathrm{min}^{-1}$ ) at $400^{\circ} \mathrm{C}$ for $2 \mathrm{~h}$. As reference, $\mathrm{Ag}-\mathrm{AgCl}$ sample was prepared via photo-reduction method according to the same method as $\mathrm{Ag}-\mathrm{AgCl} / \mathrm{CeO}_{2}$.

\subsection{Characterization of the Catalysts}

The morphology characterization of the samples was performed on a scanning electron microscope (SEM, LEO1530VP), transmission electron microscopy (TEM, JEOL JEM 2010) using a $200 \mathrm{kV}$ accelerating voltage.
The crystal structures of the samples were examined by $\mathrm{XRD}$ (D/max-IIIA, Japan) using $\mathrm{Cu} \mathrm{K} \alpha$ as the radiation source. UV-Vis diffuse reflection absorption spectra (UV-Vis/DRS) of the samples were recorded by an UVVis spectrometer (U3010, Hitachi) equipped with an integrating sphere accessory in the diffuse reflectance mode (R) and $\mathrm{BaSO}_{4}$ as a reference material. The chemical valences of $\mathrm{Ag}$ in the samples were analyzed by X-ray photoelectron spectroscopy (XPS, VG Scientific, ESCALAB MKII) using $\mathrm{Al} \mathrm{K} \alpha$ radiation (1486.71 eV). Spectra correction was conducted by using a $\mathrm{C} 1 \mathrm{~s}$ binding energy of $284.6 \mathrm{eV}$. The BET surface areas of the samples were measured by $\mathrm{N}_{2}$ adsorption at $77 \mathrm{~K}$ using a TriStar 3000 (Micromeritics, USA) after the samples were degassed in vacuum at $120^{\circ} \mathrm{C}$ overnight. The zeta potential of catalysts in $\mathrm{KNO}_{3}\left(10^{-3} \mathrm{M}\right)$ solution were measured with a Malvern Zata-sizer (Model ZEN 2010, Malvern Instrument Co., UK) with ten consistent readings.

\subsection{Evaluation of the Adsorption Capability}

For the adsorption capability measurements, fresh dye solutions of methyl orange (MO), acid orange II (AOII) and methyl blue (MB) with concentration of $200 \mathrm{mg} \cdot \mathrm{L}^{-1}$ were prepared, respectively. $100 \mathrm{mg}$ photocatalyst sample was put into $50 \mathrm{~mL}$ the above dye solutions. The suspensions were sonicated $(40 \mathrm{KHz}, 150 \mathrm{~W})$ for $15 \mathrm{~min}$ and stirred for $1 \mathrm{~h}$ at room temperature in dark to achieve absorption equilibrium. After separation through centrifugation at $12000 \mathrm{rpm}$, the remaining dye in solution was measured by UV-Vis spectrometer after 10 times dilution. Adsorption kinetics of the samples was carried out for 2 $\mathrm{h}$ and the process was similar to the below photocatalytic reaction process without light irradiation.

\subsection{Photocatalytic Reaction}

In the experiment of photocatalytic degradation, methyl orange (MO) was adopted as a typical organic pollutant. The light source was a $500 \mathrm{~W}$ Xe-arc lamp (Nanjing Xujiang Machine-electronic Plant) equipped with wavelength cutoff filters ( $1 \mathrm{M}$ sodium nitrite solution, $\lambda \geq 400$ $\mathrm{nm}$ ) used as visible light source [30]. At each time, 100 $\mathrm{mg}$ of the powdered photocatalyst was added into a 200 $\mathrm{mL}$ solution of MO dye $\left(20 \mathrm{mg} \cdot \mathrm{L}^{-1}\right)$ in a Pyrex-glass cell at room temperature and sonicated for $15 \mathrm{~min}$ to make the powders disperse well in the solution. Then the suspension system was magnetically stirred in the dark for $60 \mathrm{~min}$ to achieve adsorption/desorption equilibrium. After that, the concentration of the MO was adjusted to the same $\left(15 \mathrm{mg} \cdot \mathrm{L}^{-1}\right)$, and then the solution was bubbled with air and irradiated with the visible-light. At regular intervals, an $8 \mathrm{~mL}$ of suspension was sampled and sepa- 
rated by centrifugation at $12,000 \mathrm{rpm}$ for $10 \mathrm{~min}$. The concentration of the remaining MO was measured by its absorbance (A) at $465 \mathrm{~nm}$ with a Hitachi UV-3010 spectrophotometer. The degradation ratio of MO was calculated by $\mathrm{X}=\left(\mathrm{A}_{0}-\mathrm{A}\right) / \mathrm{A}_{0} \times 100 \%$.

\section{Results and Discussion}

\subsection{Morphology and Structures of the Samples}

Figure 1 displays the XRD patterns of the prepared $\mathrm{AgCl}, \mathrm{CeO}_{2}, \mathrm{AgCl} / \mathrm{CeO}_{2}$ and $\mathrm{Ag}-\mathrm{AgCl} / \mathrm{CeO}_{2}$ samples. Figures 1(a) and (b) exhibit the characteristic diffracttion peaks of $\mathrm{AgCl}$ (JCPDS file No. 31-1238) and $\mathrm{CeO}_{2}$ (JCPDS file No. 43-1002), respectively. Compared with Figure 1(b), additional peaks appear in Figure 1(c), which can be attributed to the cubic phase of $\mathrm{AgCl}$, indicating that a crystalline cubic phase $\mathrm{AgCl}$ was formed on $\mathrm{CeO}_{2}$. After irradiation with mercury lamp, the diffracttion peak of metallic Ag (JCPDS file No. 65-2871) appears in Figure 1d due to the photo-reduction of some $\mathrm{Ag}^{+}$in $\mathrm{AgCl}$ to $\mathrm{Ag}^{0}$. The reduced $\mathrm{Ag}$ atoms aggregate to form small silver nanocrystals with the cubic phase of $\mathrm{Ag}$ (111) located at $38.1^{\circ}$, corresponding to $2.36 \AA$ of lattice space, and then deposit on the surface of $\mathrm{AgCl}$
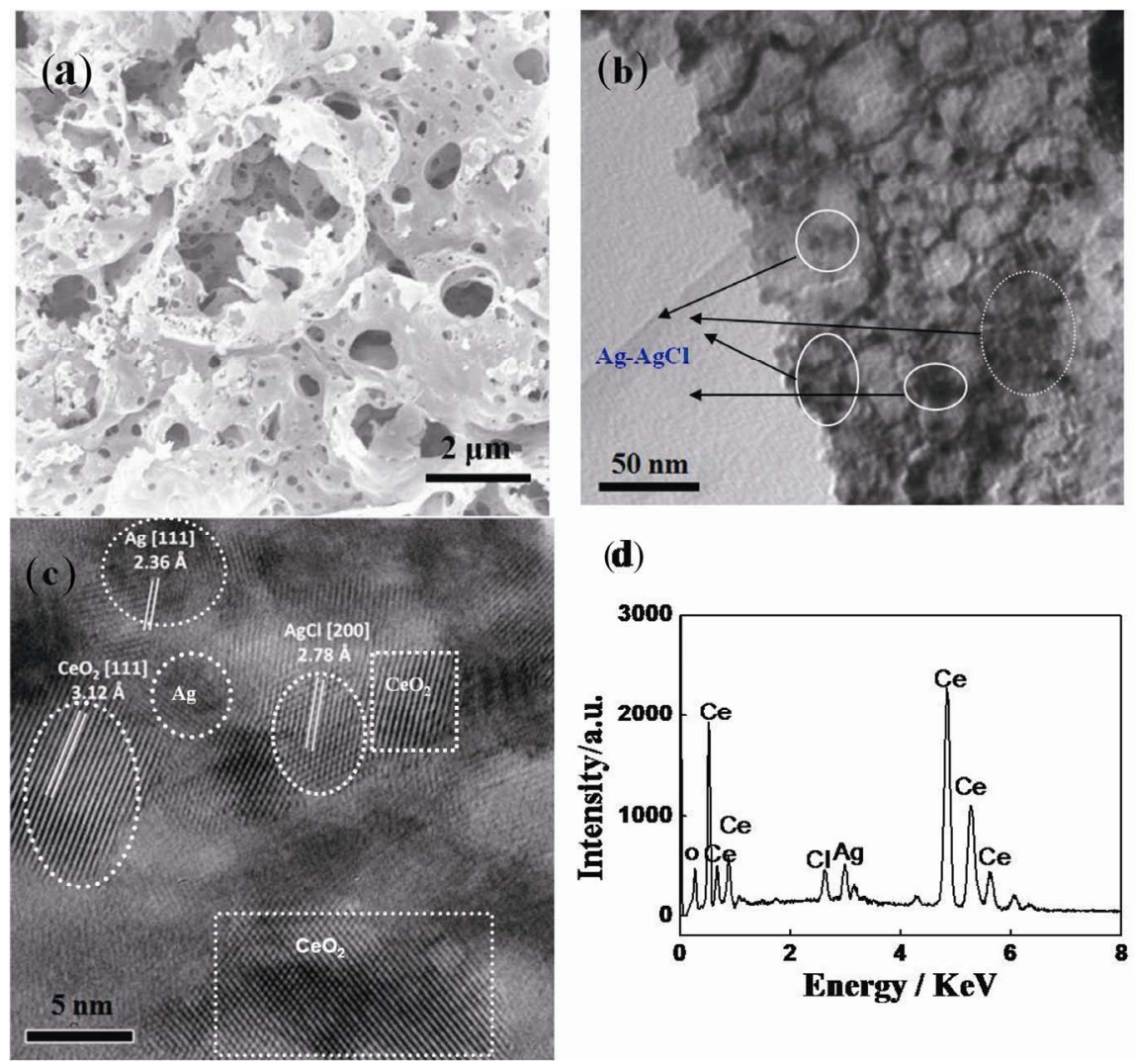

(d)

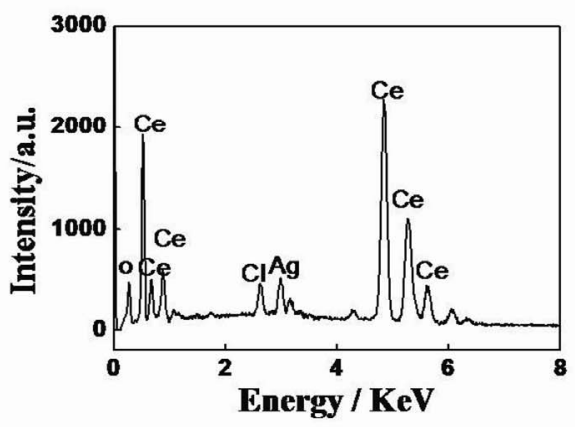

particles. (c); and $\mathrm{Ag}-\mathrm{AgCl} / \mathrm{CeO}_{2}$ (d).

Figure 2. SEM (a) and TEM; (b ) and HRTEM; (c) Images and EDS; (d) Pattern of Ag-AgCl/CeO 2.

Figure 2 shows the SEM, TEM and EDS results of the prepared $\mathrm{Ag}-\mathrm{AgCl} / \mathrm{CeO}_{2}$. According to Figure 2 (a) and (b), $\mathrm{CeO}_{2}$ presents a porous structure and $\mathrm{Ag} / \mathrm{AgCl} \mathrm{NPs}$ disperse well on the surface of $\mathrm{CeO}_{2}$ with diameter in the range of $10-30 \mathrm{~nm}$. To demonstrate the formation of silver nanoparticles on silver chloride nanoparticles,

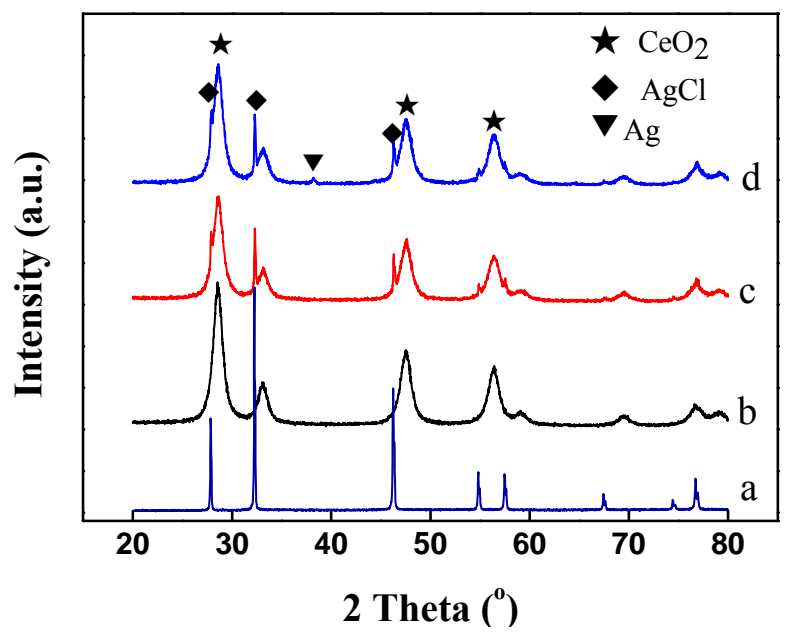

Figure 1. $\mathrm{XRD}$ patterns of $\mathrm{AgCl}(\mathrm{a}) ; \mathrm{CeO}_{2}(\mathrm{~b}) ; \mathrm{AgCl} / \mathrm{CeO}_{2}$ 
high resolution-TEM analysis was shown in Figure 2(c). Some lattice stripes with different orienttations could be observed clearly in Figure 2(c). The characteristic values of lattice constant are 2.36, 2.78 and $3.12 \AA$ corresponding to $\mathrm{Ag}(111), \mathrm{AgCl}(200)$ and $\mathrm{CeO}_{2}$ (111), respecttively, which are coincident with the strong diffraction peaks of $\mathrm{Ag}, \mathrm{AgCl}$ and $\mathrm{CeO}_{2}$ from XRD results. The energy dispersive X-ray spectroscopy (EDS), as shown in Figure 2(d), also confirmed the existence of $\mathrm{Ce}, \mathrm{O}$, $\mathrm{Ag}$ and $\mathrm{Cl}$ in $\mathrm{Ag}-\mathrm{AgCl} / \mathrm{CeO}_{2}$, and the atomic percentages (\%) of $\mathrm{Ag}$ and $\mathrm{Cl}$ in $\mathrm{Ag} / \mathrm{AgCl} / \mathrm{CeO}_{2}$ sample is about 0.68 and 0.41 . The atomic radio of $\mathrm{Ag}: \mathrm{Cl}>1$, which further confirmed that the process of $\mathrm{Ag}^{+}$reducetion to $\mathrm{Ag}^{0}$ happened and some $\mathrm{Ag}^{0}$ existed in the form of metallic Ag.

The chemical status of $\mathrm{Ag}$ from $\mathrm{AgCl} / \mathrm{CeO}_{2}$ and $\mathrm{Ag}-\mathrm{AgCl} / \mathrm{CeO}_{2}$ were further analyzed by XPS, as shown in Figure 3. Before irradiation, the $\mathrm{Ag} 3 \mathrm{~d}_{5 / 2}$ and $\mathrm{Ag} 3 \mathrm{~d}_{3 / 2}$ appear at the binding energies of $373.6 \mathrm{eV}$ and $367.6 \mathrm{eV}$, respectively. After irradiation, the corresponding peaks shift to the binding energies of $373.3 \mathrm{eV}$ and $367.3 \mathrm{eV}$, respectively. The difference of $\mathrm{Ag} 3 \mathrm{~d}$ binding energy between $\mathrm{AgCl} / \mathrm{CeO}_{2}$ and $\mathrm{Ag}-\mathrm{AgCl} / \mathrm{CeO}_{2}$ is attributed to the metallic $\mathrm{Ag}$ in the $\mathrm{Ag}-\mathrm{AgCl} / \mathrm{CeO}_{2}[31]$.

The UV-Vis diffuse-reflectance spectra of $\mathrm{CeO}_{2}, \mathrm{AgCl} /$ $\mathrm{CeO}_{2}$ and $\mathrm{Ag}-\mathrm{AgCl} / \mathrm{CeO}_{2}$ were compared in Figure 4. The $\mathrm{CeO}_{2}$ (Figure 4 (a)) only exhibits a weak absorption in the visible light region around $400 \mathrm{~nm}-450 \mathrm{~nm}$.

The addition of $\mathrm{AgCl}$ doesn't enhance the absorption of $\mathrm{CeO}_{2}$ due to the large band gaps of $\mathrm{AgCl}$ with a direct band gap of $5.15 \mathrm{eV}(241 \mathrm{~nm})$ and an indirect band gap of $3.25 \mathrm{eV}(382 \mathrm{~nm})$ [32] (Figure 4(b)). In contrast to $\mathrm{AgCl} / \mathrm{CeO}_{2}$ and $\mathrm{CeO}_{2}, \mathrm{Ag}-\mathrm{AgCl} / \mathrm{CeO}_{2}$ has a strong adsorption in the visible region of $400-700 \mathrm{~nm}$ (Figure 4(c)), which is attributed to the plasmonic resonance of $\mathrm{Ag}$ NPs deposited on $\mathrm{AgCl} / \mathrm{CeO}_{2}$ particles. It also further confirmed the formation of $\mathrm{Ag}$ NPs in the as-synthesized $\mathrm{Ag}-\mathrm{AgCl} / \mathrm{CeO}_{2}$ catalyst.

On the basis of the above XRD, EDS, XPS, UV-Vis, SEM and TEM analysis, it can be confirmed that Ag$\mathrm{AgCl}$ NPs deposited uniformly on the surface of $\mathrm{CeO}_{2}$ and that some $\mathrm{Ag}^{+}$in $\mathrm{AgCl}$ was reduced to $\mathrm{Ag}^{0}$ and thus $\mathrm{Ag}^{0}$ and $\mathrm{AgCl}$ coexist in the $\mathrm{Ag}-\mathrm{AgCl} / \mathrm{CeO}_{2}$ catalyst.

\subsection{The Adsorption Behaviors of Samples}

Figure 5 shows the adsorption kinetics of the catalysts to MO. After $30 \mathrm{~min}$, all of the catalysts almost reach adsorption equilibrium. After 2 hours, about $29 \%$ of MO was adsorbed onto $\mathrm{Ag}-\mathrm{AgCl} / \mathrm{CeO}_{2}$. Under the same condition, about $83 \%, 63 \%$ and $33 \%$ of $\mathrm{MO}$ were adsorbed onto $\mathrm{AgCl} / \mathrm{CeO}_{2}, \mathrm{Ag} / \mathrm{CeO}_{2}$ and $\mathrm{CeO}_{2}$, respectively. $\mathrm{AgCl} / \mathrm{CeO}_{2}$ shows the strongest adsorption capability to MO.

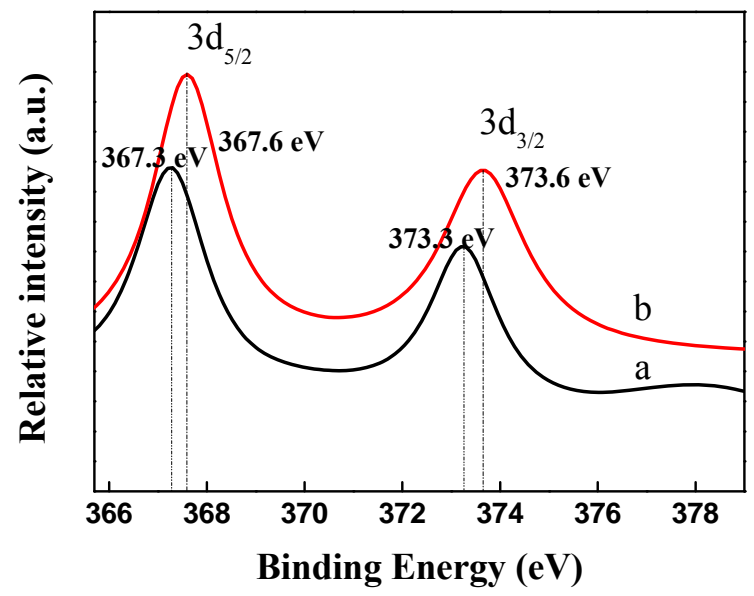

Figure 3. XPS spectra of $\mathrm{Ag} 3 \mathrm{~d}$ of $\mathrm{Ag}-\mathrm{AgCl} / \mathrm{CeO}_{2}$ (a) and $\mathrm{AgCl} / \mathrm{CeO}_{2}$ (b).

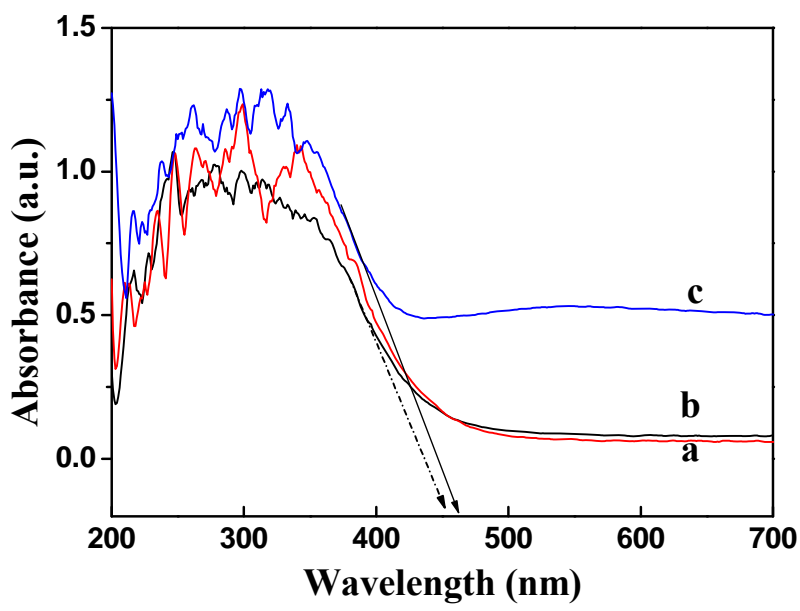

Figure 4. UV-Vis diffuse-reflectance spectra of $\mathrm{CeO}_{2}$ (a); $\mathrm{AgCl} / \mathrm{CeO}_{2}$ (b) and $\mathrm{Ag}-\mathrm{AgCl} / \mathrm{CeO}_{2}$ (c).

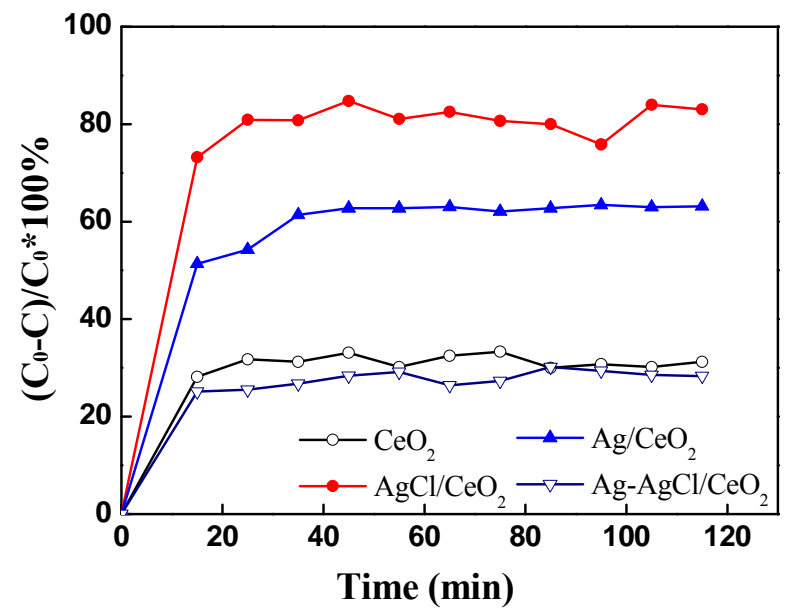

Figure 5. Adsorption kinetics of MO on the catalysts in dark. 
The adsorption of these catalysts to MO and other organic dyes, such as MB and AOII were listed in Table 1. From Table 1, it can be concluded that all of the catalysts show higher absorption capability to anionic dyes, i.e., $\mathrm{MO}$ and AOII. But they are inactive to cationic dye MB. It is interesting that $\mathrm{AgCl} / \mathrm{CeO}_{2}$ has the strongest adsorption ability to both $\mathrm{MO}$ and AOII among the three catalysts, although they have almost the same BET surface areas (Table 1). From the Zeta potential listed in Table 1, it can be seen that $\mathrm{AgCl} / \mathrm{CeO}_{2}$ has the highest zeta potential among the three catalysts, which means that the catalyst with more positive zeta potential owns the stronger adsorption capability to the anionic charged dyes. From these results, it is reasonable to conclude that the adsorption of the catalysts to dyes is due to the strong electrostatic interaction between anionic dyes and positively charged surfaces of the catalysts.

\subsection{Photocatalytic Performances of Samples}

The photocatalytic activity of the catalysts was evaluated by photocatalytic degradation of MO aqueous solution under visible light irradiation. In order to avoid the effects of the adsorption on the photodegradation efficiency, the initial concentration of the MO was adjust to the same level $\left(15 \mathrm{mg} \cdot \mathrm{L}^{-1}\right)$ after the adsorption equilibrium. Figure 6 shows the degradation ratios of MO dye over different catalysts under visible light irradiation. It can be seen that the $\mathrm{CeO}_{2}$ shows rather poor photocatalytic activity (Figure 6 (a)) with less than $5 \%$ of MO degradation ratio under visible light irradiation in $120 \mathrm{~min}$. For $\mathrm{Ag} / \mathrm{CeO}_{2}$ sample with only $\mathrm{Ag}$ immobilized on $\mathrm{CeO}_{2}$, it shows almost the same poor activity as that of $\mathrm{CeO}_{2}$ (Figure 6(b)). For $\mathrm{AgCl} / \mathrm{CeO}_{2}$, almost $16 \%$ of $\mathrm{MO}$ could be degraded under the same condition (Figure 6(d)). The enhanced photocatalytic activity of $\mathrm{AgCl} / \mathrm{CeO}_{2}$ could be attributed to the synergy between the photosensitive $\mathrm{AgCl}$ and $\mathrm{CeO}_{2}$. Under visible-light irradiation, the photogenerated electron-hole pairs were formed on the surface of $\mathrm{CeO}_{2}$. The photoexcited electrons were separated into two parts: One part of them were scavenged by oxygen on the catalyst surface to produce $\mathrm{O}_{2}^{-}$active species, the other part transferred to $\mathrm{AgCl}$ to reduce a small amount of $\mathrm{Ag}^{+}$to $\mathrm{Ag}^{0}$ depositing on the surface of $\mathrm{AgCl}$ NPs. From Figure 6d, it can also be seen that the degradation ratio of $\mathrm{MO}$ on $\mathrm{AgCl} / \mathrm{CeO}_{2}$ becomes distinct after $40 \mathrm{~min}$ because of the formation of Ag NPs on the surface of $\mathrm{AgCl} / \mathrm{CeO}_{2}$ surface. For $\mathrm{Ag}-\mathrm{AgCl} / \mathrm{CeO}_{2}$, the degradation ratio of $\mathrm{MO}$ reaches $90 \%$ in $120 \mathrm{~min}$ (Figure 6(e)), which is more than 5 and 16 times those of $\mathrm{AgCl} /$ $\mathrm{CeO}_{2}$ and $\mathrm{Ag} / \mathrm{CeO}_{2}$, respectively. It is proven that $\mathrm{Ag}$ NPs with surface plasmon resonance dramatically enhanced the photocatalytic activity under the visible-light ir- radiation. In order to estimate the role of $\mathrm{CeO}_{2}$, the photocatalytic degradation of $\mathrm{MO}$ with $\mathrm{Ag}-\mathrm{AgCl}$ sample with same $\mathrm{Ag} / \mathrm{AgCl}$ content as $\mathrm{Ag}-\mathrm{AgCl} / \mathrm{CeO}_{2}$ were shown in Figure 6(c). It can be seen that $\mathrm{Ag}-\mathrm{AgCl}$ catalyst shows lower activity with less than 10\% MO being degraded. All the results above suggest that $\mathrm{Ag}, \mathrm{AgCl}$ and $\mathrm{CeO}_{2}$ in the $\mathrm{Ag}-\mathrm{AgCl} / \mathrm{CeO}_{2}$ catalyst exhibited synergistic effects.

In order to investigate the role of $\mathrm{Ag}$ in the $\mathrm{Ag}-\mathrm{AgCl} /$ $\mathrm{CeO}_{2}$ further, the photodegradation of $\mathrm{MO}$ with $\mathrm{Ag}-\mathrm{AgCl} /$ $\mathrm{CeO}_{2}$ and $\mathrm{AgCl} / \mathrm{CeO}_{2}$ were studied under different visiblelight, respectively, as shown in Figure 7. The visible-light with different wavelength was obtained with different filter. From Figure 7(d), at the wavelength $\lambda>420 \mathrm{~nm}$, no significant degradation was observed on $\mathrm{AgCl} / \mathrm{CeO}_{2}$, which is due to the weak visible-light absorption of $\mathrm{AgCl} / \mathrm{CeO}_{2}$ in this wavelength range. While $\mathrm{Ag}-\mathrm{AgCl} /$ $\mathrm{CeO}_{2}$ exhibited very high photocatalytic activity at the same condition, which means that Ag plays very important role in the photocatalytic degradation of MO. One is the plasmon resonance of Ag NPs and the other is the enhancing separation of photo-excited electrons and holes. With wavelength changing from $\lambda>400 \mathrm{~nm}$ to $\lambda>420$

Table 1. Adsorption capacity and zeta potential of different catalysts

\begin{tabular}{cccccc}
\hline \multirow{2}{*}{ Catalysts } & \multicolumn{3}{c}{$\begin{array}{c}\text { Adsorption Capacity } \\
\left(\mu \mathrm{mol} \cdot \mathrm{g}^{-1}\right)\end{array}$} & $\begin{array}{c}\text { Zeta potential } \\
(\mathrm{mV})\end{array}$ & $\begin{array}{c}\mathrm{BET} \text { surface } \\
\text { area }\left(\mathrm{m}^{2} \cdot \mathrm{g}^{-1}\right)\end{array}$ \\
\cline { 2 - 4 } & $\mathrm{MO}$ & $\mathrm{MB}$ & $\mathrm{AOII}$ & & 51.2 \\
\hline $\mathrm{AgCl} / \mathrm{CeO}_{2}$ & 209.8 & 0 & 185.9 & 26.4 & 53.3 \\
$\mathrm{Ag} / \mathrm{CeO}_{2}$ & 125.3 & 0 & 164.5 & 21.8 & 56.4 \\
$\mathrm{Ag}-\mathrm{AgCl} / \mathrm{CeO}_{2}$ & 77.3 & 0 & 73.71 & 20.5 & 5 \\
\hline
\end{tabular}

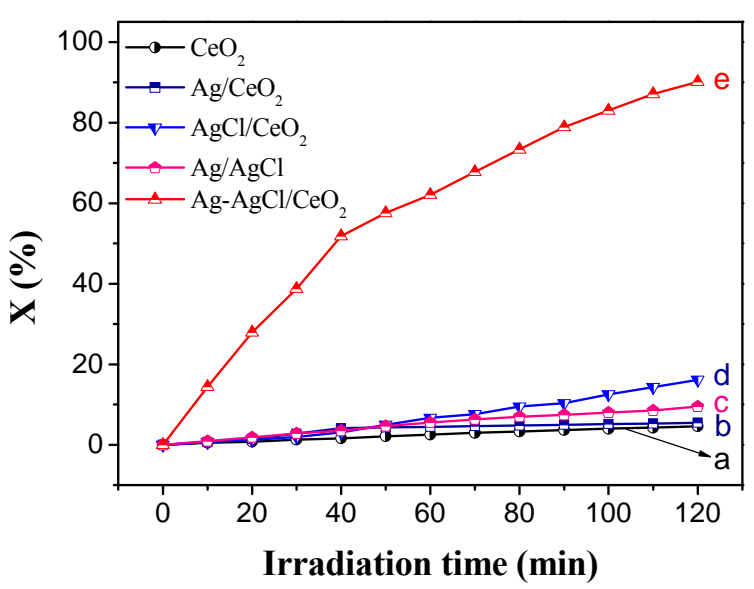

Figure 6. The degradation ratios of MO under visible light irradiation on the catalysts: $\mathrm{CeO}_{2}(\mathrm{a}) ; \mathrm{Ag} / \mathrm{CeO}_{2}$ (b); $\mathrm{Ag}-\mathrm{AgCl}$ (c); $\mathrm{AgCl} / \mathrm{CeO}_{2}$ (d); and $\mathrm{Ag}-\mathrm{AgCl} / \mathrm{CeO}_{2}$ (e). 
$\mathrm{nm}$, the photocatalytic activity of $\mathrm{Ag}-\mathrm{AgCl} / \mathrm{CeO}_{2}$ changes little and the change is even smaller than that for $\mathrm{AgCl} /$ $\mathrm{CeO}_{2}$, which indicates that the plasmon resonance of $\mathrm{Ag}$ NPs is the main role in the photocatalytic degradation of MO under visible-light [28].

The effect of photo-reduction time of $\mathrm{AgCl} / \mathrm{CeO}_{2}$ on the photocatalytic degradation of $\mathrm{MO}$ was also examined. The result showed that $\mathrm{Ag}-\mathrm{AgCl} / \mathrm{CeO}_{2}$ with photo-reduction time of $20 \mathrm{~min}$ exhibits the highest photocatalytic activity than those with reduction time of $10 \mathrm{~min}$ and 30 min, indicating that the photocatalytic activity greatly depends on the $\mathrm{Ag} \mathrm{NPs}$ content on $\mathrm{AgCl} / \mathrm{CeO}_{2}$.

As a useful photocatalyst, the stability is rather important for its practical application. Figure 8 shows the reusability of $\mathrm{Ag}-\mathrm{AgCl} / \mathrm{CeO}_{2}$ catalyst for $\mathrm{MO}$ photocatalytic degradation. Although the degradation ratio of $\mathrm{MO}$ decreased slightly after each run, the catalyst still exhibited efficient activity with about $82 \%$ of the degradation ratio at the fifth run. So, the as-prepared catalyst could remain $90 \%$ of the initial activity after five recycling run, suggesting the $\mathrm{Ag}-\mathrm{AgCl} / \mathrm{CeO}_{2}$ has good stability and can be used repeatedly.

\subsection{Discussion on the Reaction Mechanism}

Several studies have confirmed that $\mathrm{Ce} 4 \mathrm{f}$ plays vital role for $\mathrm{CeO}_{2}$ in photocatalytic process [33] and they demonstrated that electrons can be more easily injected into $4 \mathrm{f}$ band of $\mathrm{CeO}_{2}$ because the potential of $4 \mathrm{f}$ band of $\mathrm{CeO}_{2}$ is a little more positive than that of the conduction band of $\mathrm{TiO}_{2}$. $\mathrm{CeO}_{2}$ was chosen as the semiconductor in this work has other reason, that is, $\mathrm{CeO}_{2}$ has excellent electrontransfer mediator ability under visible light [9], which is helpful to further enhance its charge separation ability.

For a plasmonic photocatalyst, the major photocatalytic reaction procedure under visible light irradiation can be summarized by the following steps, schematically shown in Figure 9, which is similar with Huang's mechanism of $\mathrm{Ag} @ \mathrm{AgCl}$ plasmonic photocatalysis and Hu's plasmon-induced charge separation mechanism [22,27]. First, due to the SPR ability of noble metal NPs, Ag NPs absorb visible light and generate electron-hole pairs when the visible light is illuminated. Then the photogenerated electrons are injected to the $4 \mathrm{f}$ band of $\mathrm{CeO}_{2}$ and captured by the oxygen on the surface of $\mathrm{CeO}_{2}$ to generate superoxide radical that can then form hydrogen peroxide $\left(\mathrm{H}_{2} \mathrm{O}_{2}\right)$, hydroperoxy $\left(\mathrm{HO}_{2}{ }^{\cdot}\right)$ and hydroxyl $(\mathrm{OH} \cdot)$. Except for the generation of these common photocatalytic active species, another reactive radical species $\mathrm{Cl}^{0}$ is formed when the holes transfer to $\mathrm{AgCl}$ with its surface negatively charged by $\mathrm{Cl}^{-}$after $\mathrm{Ag}^{+}$reduction. $\mathrm{Cl}^{0}$ can oxidize $\mathrm{MO}$ and be reduced to $\mathrm{Cl}^{-}$again. So, the system is cyclic and stable.

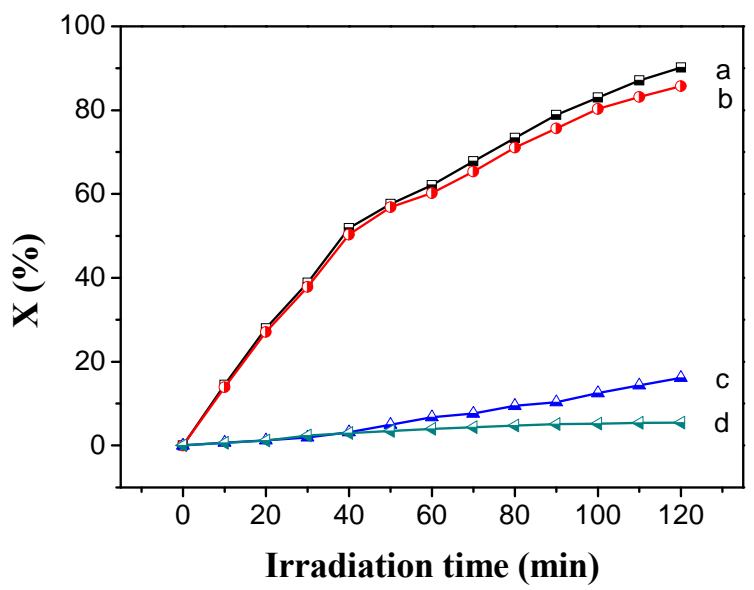

Figure 7. The degradation ratios of MO dye in solution (20 $\left.\mathrm{mg} \cdot \mathrm{L}^{-1}\right)$ under visible light with $\lambda \geq 400 \mathrm{~nm}(\mathrm{a}, \mathrm{c})$ and $\lambda \geq$ $420 \mathrm{~nm}(\mathrm{~b}, \mathrm{~d})$ on the catalysts: $\mathrm{Ag}-\mathrm{AgCl} / \mathrm{CeO}_{2}(\mathrm{a}, \mathrm{b})$ and $\mathrm{AgCl} / \mathrm{CeO}_{2}$ (c, d).

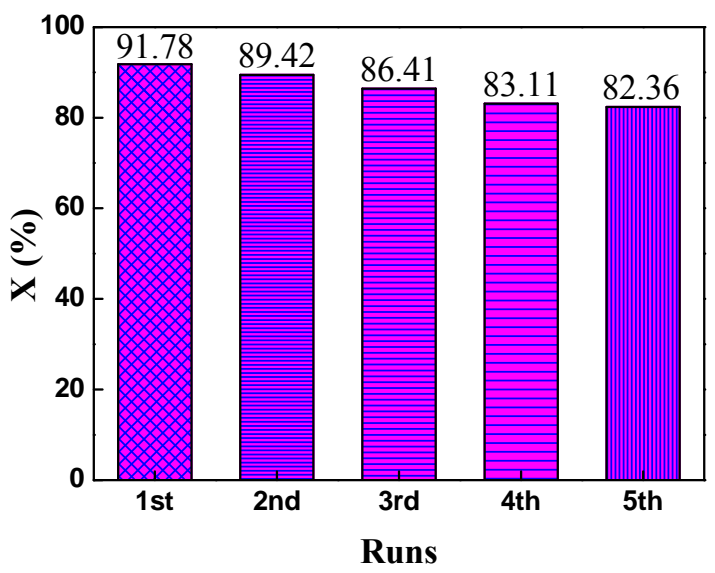

Figure 8. Reusability of $\mathrm{Ag}-\mathrm{AgCl} / \mathrm{CeO}_{2}$ catalyst for $\mathrm{MO}$ photocatalytic degradation under visible light irradiation. MO initial concentration of $15 \mathrm{mg} \cdot \mathrm{L}^{-1}$; catalyst concentration of $0.5 \mathrm{~g} \cdot \mathrm{L}^{-1}$ and reaction time of $2 \mathrm{~h}$.

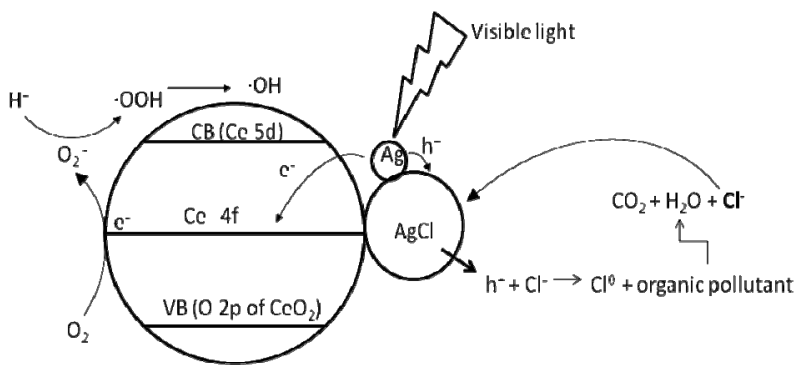

Figure 9. Schematic diagram for the charge separation on $\mathrm{Ag}-\mathrm{AgCl} / \mathrm{CeO}_{2}$ catalyst under visible light irradiation.

\section{Conclusions}

The plasmonic photocatalyst $\mathrm{Ag}-\mathrm{AgCl} / \mathrm{CeO}_{2}$ was prepared with an easy achieving and controlling method. 
The results show that $\mathrm{Ag}-\mathrm{AgCl} / \mathrm{CeO}_{2}$ has high photocatalytic activity and good stability for MO photocatalytic degradation under visible light irradiation. With the synergistic effects of $\mathrm{Ag}$ and $\mathrm{AgCl}$, an improved visiblelight photocatalytic activity was achieved. Ag- $\mathrm{AgCl} / \mathrm{CeO}_{2}$ will be a potentially promising plasmonic photocatalysts for organic pollutant degradation and water purifycation.

\section{Acknowledgements}

The authors thank the National Natural Science Foundation of China (No. 20873044) and the Guangdong Provincial Science and Technology Project of China (No. 2011B050400014).

\section{References}

[1] A. Fujishima and K. Honda, "Electrochemical Photocatalysis of Water at a Semiconductor Electrode," Nature, Vol. 238, No. 5358, 1972, pp. 37-38.

[2] B. Ohtani, R. M. Bowman, D. P. Colombo, H. Kominami, H. Noguchi and K. Uosaki, "Femtosecond Diffuse Reflectance Spectroscopy of Aqueous Titanium(IV) Oxide Suspension: Correlation of Electron-Hole Recombination Kinetics with Photocatalytic Activity," Chemistry Letters, Vol. 27, No. 7, 1998, pp. 579-580. doi:10.1246/cl.1998.579

[3] S. Ikeda, N. Sugiyama, B. Pal, G. Marci, L. Palmisano, H. Noguchi, et al., "Photocatalytic Activity of Transition-MetalLoaded Titanium(IV) Oxide Powders Suspended in Aqueous Solutions: Correlation with Electron-Hole Recombination Kinetics," Physical Chemistry Chemistry Physics, Vol. 3, No. 2, 2001, pp. 267-273. doi:10.1039/b008028o

[4] A. Fujishima, X. T. Zhang and D. A. Tryk, "TiO ${ }_{2}$ Photocatalysis and Related Surface Phenomena," Surface Science Reports, Vol. 63, No. 12, 2008, pp. 515-582. doi:10.1016/j.surfrep.2008.10.001

[5] T. W. Kim, S. J. Hwang, S. H. Jhung, J. S. Chang, H. Park, W. Choi, et al., "Bifunctional Heterogeneous Catalysts for Selective Epoxidation and Visible Light Driven Photolysis: Nickel Oxide-Containing Porous Nanocomposite," Advanced Materials, Vol. 20, No. 3, 2008, pp. 539-542. doi:10.1002/adma.200701677

[6] J. Li, W. H. Ma, Y. P. Huang, X. Tao, J. C. Zhao and Y. M. $\mathrm{Xu}$, "Oxidative Degradation of Organic Pollutants Utilizing Molecular Oxygen and Visible Light over a Supported Catalyst of Fe(bpy) ${ }_{3}^{2+}$ in Water," Applied Catalysis B: Environmental, Vol. 48, No. 1, 2004, pp. 17-24. doi:10.1016/j.apcatb.2003.09.003

[7] J. C. Zhao, C. C. Chen and W. H. Ma, "Photocatalytic Degradation of Organic Pollutants under Visible Light Irradiation," Topics in Catalysis, Vol. 35, No. 3-4, 2005, pp. 269-278. doi:10.1007/s11244-005-3834-0

[8] M. D. Hernandez-Alonso, F. Fresno, S. Suarez and J. M. Coronado, "Development of Alternative Photocatalysts to $\mathrm{TiO}_{2}$ : Challenges and Opportunities," Energy \& Environmental Science, Vol. 2, No. 12, 2009, pp. 1231-1257. doi:10.1039/b907933e
[9] P. F. Ji, J. L. Zhang, F. Chen and M. Anpo, "Study of Adsorption and Degradation of Acid Orange 7 on the Surface of $\mathrm{CeO}_{2}$ under Visible Light Irradiation," Applied Catalysis B: Environmental, Vol. 85, No. 3-4, 2009, pp. 148154. doi:10.1016/j.apcatb.2008.07.004

[10] G. R. Bamwenda, K. Sayama and H. Arakawa, "The Photoproduction of $\mathrm{O}_{2}$ from a Suspension Containing $\mathrm{CeO}_{2}$ and $\mathrm{Ce}^{4+}$ Cations as an Electron Acceptor," Chemistry Letters, Vol. 28, No. 10, 1999, pp. 1047-1048.

doi:10.1246/cl.1999.1047

[11] Q. Fu, H. Saltsburg and M. Flytzani-Stephanopoulos, "Active Nonmetallic Au and Pt Species on Ceria Based Water Gas Shift Catalysts," Science, Vol. 301, No. 5635, 2003, pp. 935-938. doi:10.1126/science.1085721

[12] E. Perry Murray, T. Tsai and S. A. Barnett, "A DirectMethane Fuel Cell with Ceria-Based Anode," Nature, Vol. 400, No. 6745, 1999, pp. 649-651. doi:10.1038/23220

[13] A. Corma, P. Atienzar, H. Garcia and J. Y. Chane-Ching, "Hierarchically Mesostructured Doped $\mathrm{CeO}_{2}$ with Potential for Solar-Cell Use," Nature Materials, Vol. 3, No. 6, 2004, pp. 394-397. doi:10.1038/nmat1129

[14] V. Subramanian, E. Wolf and P. V. Kamat, "SemiconductorMetal Composite Nanostructures. To What Extent Do Metal Nanoparticles Improve the Photocatalytic Activity of $\mathrm{TiO}_{2}$ Films," Journal of Physical Chemistry B, Vol. 105, No. 46, 2001, pp. 11439-11446. doi:10.1021/jp011118k

[15] M. Miyauchi, A. Nakajima, T. Watanabe and K. Hashimoto, "Photocatalysis and Photoinduced Hydrophilicity of Various Metal Oxide Thin Films," Chemistry of Materials, Vol. 14, No. 6, 2002, pp. 2812-2816. doi:10.1021/cm020076p

[16] L. B. Khalil, W. E. Mourad and M. W. Rophael, "Photocatalytic Reduction of Environmental Pollutant Cr(VI) over some Semiconductors under UV/Visible Light Illumination," Applied Catalysis B: Environmental, Vol. 17, No. 3 1998, pp. 267-273. doi:10.1016/S0926-3373(98)00020-4

[17] J. G. Yu, G. P. Dai and B. B. Huang, "Fabrication and Characterization of Visible-Light-Driven Plasmonic Photocatalyst $\mathrm{Ag} / \mathrm{AgCl} / \mathrm{TiO}_{2} \mathrm{TiO}_{2}$ Nanotube Arrays," Journal of Physical Chemistry C, Vol. 113, No. 37, 2009, pp. 16394 16401. doi:10.1021/jp905247j

[18] K. Awazu, M. Fujimaki, C. Rockstuhl, J. Tominaga, H. Murakami, Y. Ohki, et al., "A Plasmonic Photocatalyst Consisting of Silver Nanoparticles Embedded in Titanium Dioxide," Jouranl of the American Chemical Society, Vol. 130, No. 5, 2008, pp. 1676-1680. doi:10.1021/ja076503n

[19] X. Chen, H. Y. Zhu, J. C. Zhao, Z. T. Zheng and X. P. Gao, "Visible-Light-Driven Oxidation of Organic Contaminants in Air with Gold Nanoparticle Catalysts on Oxide Supports," Angewandte Chemie (International Edition), Vol. 47, No. 29, 2008, pp. 5353-5356. doi:10.1002/anie.200800602

[20] S. M. Sun, W. Z. Wang, L. Zhang, M. Shang and L. Wang, "Ag@C Core/Shell Nanocomposite as a Highly Efficient Plasmonic Photocatalyst," Catalysis Communications, Vol. 11, No. 4, 2009, pp. 290-293. doi:10.1016/j.catcom.2009.09.026

[21] S. Rodrigues, S. Uma, I. N. Martyanov and K. J. Klabunde, 
“AgBr/Al-MCM-41 Visible-Light Photocatalyst for GasPhase Decomposition of $\mathrm{CH}_{3} \mathrm{CHO}$," Journal of Catalysis, Vol. 233, No.2, 2005, pp. 405-410. doi:10.1016/j.jcat.2005.05.011

[22] P. Wang, B. B. Huang, X. Y. Qin, X. Y. Zhang, Y. Dai, J. Y. Wei, et al., “Ag@AgCl: A Highly Efficient and Stable Photocatalyst Active under Visible Light," Angewandte Chemie (International Edition), Vol. 47, No. 41, 2008, pp. 7931-7933. doi:10.1002/anie.200802483

[23] P. Wang, B. B. Huang, X. Y. Zhang, X. Y. Qin, H. Jin, Y. Dai, et al., "Highly Efficient Visible-Light Plasmonic Photocatalyst Ag@AgBr," Chemistry-A European Journal, Vol. 15, No. 8, 2009, pp. 1821-1824. doi:10.1002/chem.200802327

[24] P. Wang, B. B. Huang, Q. Q. Zhang, X. Y. Zhang, X. Y. Qin, Y. Dai, et al, "Highly Efficient Visible Light Plasmonic Photocatalyst Ag@Ag(Br,I)," Chemistry-A European Journal, Vol. 16, No. 33, 2010, pp. 10042-10047. doi: 10.1002/chem.200903361

[25] P. Wang, B. B. Huang, Z. Z. Lou, X. Y. Zhang, X. Y. Qin, Y. Dai, et al, "Synthesis of Highly Efficient Ag@AgCl Plasmonic Photocatalysts with Various Structures," Chemistry-A European Journal, Vol. 16, No. 2, 2010, pp. 538-544. doi:10.1002/chem.200901954

[26] Y. Tian and T. Tatsuma, "Mechanisms and Applications of Plasmon-Induced Charge Separation at $\mathrm{TiO}_{2}$ Films Loaded with Gold Nanoparticles," Jouranl of the American Chemical Society, Vol. 127, No. 20, 2005, pp. 76327637. doi:10.1021/ja042192u

[27] X. F. Zhou, C. Hu, X. X. Hu, T. W. Peng and J. H. Qu, "Plasmon-Assisted Degradation of Toxic Pollutants with $\mathrm{Ag}-\mathrm{AgBr} / \mathrm{Al}_{2} \mathrm{O}_{3}$ under Visible-Light Irradiation," Journal of Physical Chemistry C, Vol. 114, No. 6, 2010, pp. 2746-2750. doi:10.1021/jp909697k

[28] C. Hu, T. W. Peng, X. X. Hu, Y. L. Nie, X. F. Zhou, J. H. $\mathrm{Qu}$, et al, "Plasmon-Induced Photodegradation of Toxic Pollutants with $\mathrm{Ag}-\mathrm{AgI} / \mathrm{Al}_{2} \mathrm{O}_{3}$ under Visible-Light Irradiation," Jouranl of the American Chemical Society, Vol. 132, No. 2, 2010, pp. 857-862. doi:10.1021/ja907792d

[29] C. Hu, Y. Q. Lan, J. H. Qu, X. X. Hu and A. M. Wang, "Ag/AgBr/TiO ${ }_{2}$ Visible Light Photocatalyst for Destruction of Azodyes and Bacteria," Journal of Physical Chemistry B, Vol. 110, No. 9, 2006, pp. 4066-4072. doi:10.1021/jp0564400

[30] C. Ping, L. Wei, T. L. Zhou, Y. P. Jin and M. Y. Gu, "Physical and Photocatalytic Properties of Zinc Ferrite Doped Titania under Visible Light Irradiation," Journal of Photochemistry and Photobiology A: Chemistry, Vol. 168, No. 1-2, 2004, pp. 97-101. doi:10.1016/j.jphotochem.2004.05.018

[31] J. F. Hamilton, "Physical Properties of Silver Halide Microcrystals," Photographic Science and Engineering, Vol. 18, No. 5, 1974, pp. 493-500.

[32] S. Glaus and G. Calzaferri, "The Band Structures of the Silver Halides $\mathrm{AgF}, \mathrm{AgCl}$, and $\mathrm{AgBr}$ : a Comparative Study," Photochemical \& Photobiological Sciences, Vol. 2, No. 4, 2003, pp. 398-401. doi:10.1039/b211678b

[33] F. B. Li, X. Z. Li, M. F. Hou, K. W. Cheah and W. C. H. Choy, "Enhanced Photocatalytic Activity of $\mathrm{Ce}^{3+}-\mathrm{TiO}_{2}$ for 2-Mercaptobenzothiazole Degradation in Aqueous Suspension for Odour Control," Applied Catalysis A: General, Vol. 285, No. 1-2, 2005, pp. 181-189. doi:10.1016/j.apcata.2005.02.025 